\title{
Complete Mitochondrial Genome of Echinostoma hortense (Digenea: Echinostomatidae)
}

\author{
Ze-Xuan Liu', Yan Zhang', Yu-Ting Liu, Qiao-Cheng Chang, Xin Su, Xue Fu, Dong-Mei Yue, Yuan Gao, \\ Chun-Ren Wang* \\ College of Animal Science and Veterinary Medicine, Heilongjiang Bayi Agricultural University, Daqing, Heilongjiang Province 163319, P. R. China
}

\begin{abstract}
Echinostoma hortense (Digenea: Echinostomatidae) is one of the intestinal flukes with medical importance in humans. However, the mitochondrial $(\mathrm{mt})$ genome of this fluke has not been known yet. The present study has determined the complete $\mathrm{mt}$ genome sequences of $E$. hortense and assessed the phylogenetic relationships with other digenean species for which the complete mt genome sequences are available in GenBank using concatenated amino acid sequences inferred from 12 protein-coding genes. The mt genome of $E$. hortense contained 12 protein-coding genes, 22 transfer RNA genes, 2 ribosomal RNA genes, and 1 non-coding region. The length of the mt genome of $E$. hortense was $14,994 \mathrm{bp}$, which was somewhat smaller than those of other trematode species. Phylogenetic analyses based on concatenated nucleotide sequence datasets for all 12 protein-coding genes using maximum parsimony (MP) method showed that $E$. hortense and Hypoderaeum conoideum gathered together, and they were closer to each other than to Fasciolidae and other echinostomatid trematodes. The availability of the complete mt genome sequences of $E$. hortense provides important genetic markers for diagnostics, population genetics, and evolutionary studies of digeneans.
\end{abstract}

Key words: Echinostoma hortense, complete mitochondrial DNA, echinostomatidae, phylogenetic analysis

\section{INTRODUCTION}

About 500 species of echinostomatid flukes (Echinostomatidae) had been reported in the world [1], and at least 20 species belonging to 8 genera can infect humans [2]. Among these genera, Echinostoma is the largest one, which constitutes 7 species, including E. hortense, E. angustitestis, E. cinetorchis, E. echinatum, E. ilocanum, E. macrorchis, and E. revolutum [2]. Although the majority of people infected by echinostomes have no obvious symptoms, severe infections may cause anorexia, lower extremity edema, anemia, weight loss, and dysplasia [3].

The adult worms of $E$. hortense often inhabit the small intestine of humans and many animals [3]. The parasitic fluke E. hortense was originally described from rats in Japan [4], and since then, it has been reported in South Korea and China $[2,3,5,6]$. In addition to rats, it has also been found from cats, dogs, and pigs [6-8], and more importantly, there are many infected human cases in China, Japan, and South Korea [2,3,9-

- Received 5 August 2015, revised 16 January 2016, accepted 23 January 2016.

*Corresponding author (chunrenwang@sohu.com)

†These authors contributed equally to this work.

(c) 2016, Korean Society for Parasitology and Tropical Medicine

This is an Open Access article distributed under the terms of the Creative Commons Attribution Non-Commercial License (http://creativecommons.org/licenses/by-nc/3.0) which permits unrestricted non-commercial use, distribution, and reproduction in any

medium, provided the original work is properly cited.
11]. A high prevalence of human infection by E. hortense was reported in Koje-myon, Kochang-gun, Kyongsangnam-do (Province), South Korea, up to 9.5\% [11].

Mitochondrial (mt) genome sequences provide valuable genetic markers for investigating population genetics, systematics, and phylogenetics of animal species $[12,13]$. So far, there are about 18,000 species of digenean trematodes found in the world [14], but only 32 species have complete mt genomes sequenced. In the family Echinostomatidae, only 1 species $H y$ poderaeum conoideum (KM111525) had complete mt genome reported, and no mt genome of genus Echinostoma has been available. Previous studies on E. hortense have mainly focused on their morphology, life history, and epidemiological investigations [3-11]. However, the mitochondrial genome of this fluke has not been known yet. Therefore, in the present study, we have determined the complete mt genome sequences of $E$. hortense and inferred its phylogenetic relationship with other digenean trematodes.

\section{MATERIALS AND METHODS}

\section{Parasites and total genomic DNA isolation}

Adult E. hortense worms were collected from the small intestine of a naturally infected dog in Daqing, Heilongjiang Prov- 
ince of China. The trematodes were washed in physiological saline, identified morphologically as E. hortense based on existing keys and descriptions [15], fixed in 70\% (v/v) ethanol (Yixin Biological Technology Co., Shanghai, China), and stored at $-20^{\circ} \mathrm{C}$ until use. Total genomic DNA was extracted from individual fluke using a TIANamp Genomic DNA Kit (TIANGEN, Beijing, China) according to the manufacturer's instructions, and DNA sample was stored at $-20^{\circ} \mathrm{C}$ until use. In order to independently verify the identity of the specimens, the internal transcribed spacer 2 (ITS2) was amplified from the extracted genomic DNA by PCR and sequenced according to the conventional method. The ITS2 sequences obtained were perfectly matched with that of E. hortense available in GenBank (U58101.1).

\section{Amplification, sequencing, and assembling of mt DNA fragments}

Amplification, sequencing, and assembly of mtDNA fragments were performed according to the methods previously described $[12,16]$. The 7 pairs of oligonucleotide primers were designed based on the conserved regions from published complete mtDNA sequences of Fasciola hepatica, Opisthorchis felineus, Paramphistomum cervi, and H. conoideum (Table 1). The cycling conditions were $94^{\circ} \mathrm{C}$ for 5 min (initial denaturation); then $94^{\circ} \mathrm{C}$ for $1 \mathrm{~min}$ (denaturation), $50^{\circ} \mathrm{C}$ for 1 min (annealing), $72^{\circ} \mathrm{C}$ for $1-3 \mathrm{~min}$ (extension) for 35 cycles, and a final extension at $72^{\circ} \mathrm{C}$ for $7 \mathrm{~min}$. Each PCR reaction yielded a single band, detected in a 1.0\% (w/v) agarose gel stained with ethidium-bromide. PCR products were directly sequenced on an ABI 3370 DNA sequencer at Shanghai Sangon Biotech Company (Shanghai, China) using a primer walking strategy. The

Table 1. Sequences of primers used to amplify PCR fragments of mitochondrial genome from Echinostoma hortense

\begin{tabular}{llc}
\hline Primer name & \multicolumn{1}{c}{ Sequence of primer (5'-3') } & Size $(\mathrm{kb})$ \\
\hline EH-1 & F: AATATGCAAACACACCCGACTG & $\sim 3.8$ \\
& R: CGATGTGCGTCTGTAGAGTCTAAGG & \\
EH-2 & $\begin{array}{l}\text { F: GCCTCCTGTGTTGTCTCTCGCTTA } \\
\text { R: CTCGCACCATATCCCAATTAGCC }\end{array}$ & $\sim 2.2$ \\
EH-3 & $\begin{array}{l}\text { F: GGTTATACAGAGGTT } \\
\text { R: ATAACCATAGTAACAGAA }\end{array}$ & $\sim 2.5$ \\
EH-4 & F: TCTTGTCTTGCTATGTGGCTATT \\
& R: TTAGCGGACCATCTCTTACAC \\
EH-5 & F: AGCCAGGTCGGTCTTATC \\
& R: ACCACACAACTCCGTACAATAAC \\
EH-6 & F: CGTTAGGGTGTGTCCAACTGT \\
& R: AGCAACAATCTTCTTAAGTCCATA & \\
EH-7 & F: GTGGGAGTATTAGGTCTTGTCAGG & $\sim 1.4$ \\
& R: GAACACCACTAGAATAAGGAATAC & \\
\hline
\end{tabular}

complete mtDNA sequences of $E$. hortense were assembled using DNAStar software as a sequence editor [17].

\section{Sequence analysis of $E$. hortense mt genome}

Gene annotation, genome organization, translation initiation, translation termination codons, and the boundaries between protein-coding genes of mtDNA were identified based on comparison with mt genomes of other trematodes reported previously [18]. Open reading frames and gene boundaries were confirmed by comparing with $H$. conoideum mt genome nucleotide sequences (http://blast.ncbi.nlm.nih.gov/Blast.cgi). Translation initiation and translation termination codons were identified using genetic codon table for mitochondrion in MEGA 5 [19] and also based on comparison with the mt genomes of the trematodes reported previously $[16,18]$. The codon usage profiles of 12 protein-coding genes (PCGs) and their nucleotide composition were calculated using Geneious 6.1.5 program (Biomatters Co., Auckland, New Zealand) [20]. For the analyses of transfer RNA genes, putative secondary structures of $22 \mathrm{tRNA}$ genes were identified using the program tRNAscan-SE (http://lowelab.ucsc.edu/tRNAscan-SE), or by visual identification combined with manual proofreading through anticodon and tRNA secondary structures of trematodes which are available in GenBank.

\section{Phylogenetic analysis}

To assess the phylogenetic relationship of $E$. hortense with other digenean trematodes, the complete mt genome sequences of 24 trematode species were retrieved from GenBank and employed for phylogenetic analysis. The mtDNA sequences were as follows: Clinostomum complanatum (KM923964.1), Calicophoron microbothrioides (KR337555.1), Clonorchis sinensis (JF729303), Dicrocoelium chinensis (NC_025279), Dicrocoelium dendriticum (NC_025280), Fasciola gigantica (KF543342), F. hepatica (NC_002546), Haplorchis taichui (KF214770), H. conoideum (KM111525), Metagonimus yokogawai (KC330755), Ogmocotyle sikae (KR006934.1), Opisthorchis felineus (EU921260), O. viverrini (JF739555), P. cervi (KF475773), Paramphistomum leydeni (KP341657.1), Paragonimus westermani (NC_002354) Schistosoma haematobium (DQ157222), S. japonicum (NC_002544), S. mansoni (NC_002545), S. mekongi (NC_002529), S. spindale (DQ157223), S. turkestanicum (HQ283100), Trichobilharzia regenti (NC_009680), and using Monogenea species Gyrodactylus thymalli (NC_009682) as the outgroup. The nucleotide alignments involved PCGs were generated on the basis of the pro- 
tein alignment using codon alignment amino acid sequences for 12 PCGs, which were individually aligned utilizing Clustal X 1.83 under default parameters [21]. Phylogenetic analyses were performed with the maximum parsimony (MP) method. Phylogenetic reconstructions were carried out using PAUP* Version 4.0b10 [22]. Phylograms were drawn using the Tree View program version 1.65 [23].

\section{RESULTS}

\section{Features of the mt genome of $E$. hortense}

The circular complete mt genome of $E$. hortense (GenBank accession no. KR062182) was 14,994 bp in length (Fig. 1). The mt genome encoded 36 genes: 12 PCGs (cox1-3, nad1-6, nad4L, atp6, cytb), 22 transfer RNA genes, and 2 ribosomal RNA genes ( $r r n \mathrm{~L}$ and $r r n S)$. All genes were transcribed in the same direction. The relative positions and lengths of each gene are given in Table 2. The nucleotide contents in the $\mathrm{mt}$ genome were $41.77 \%$ (T), $21.26 \%(\mathrm{~A}), 24.79 \%(\mathrm{G})$, and $12.18 \%(\mathrm{C})$, and the overall A+T content of the mt genome was $63.03 \%$.

A total of 3,349 amino acids were encoded by the E. hortense

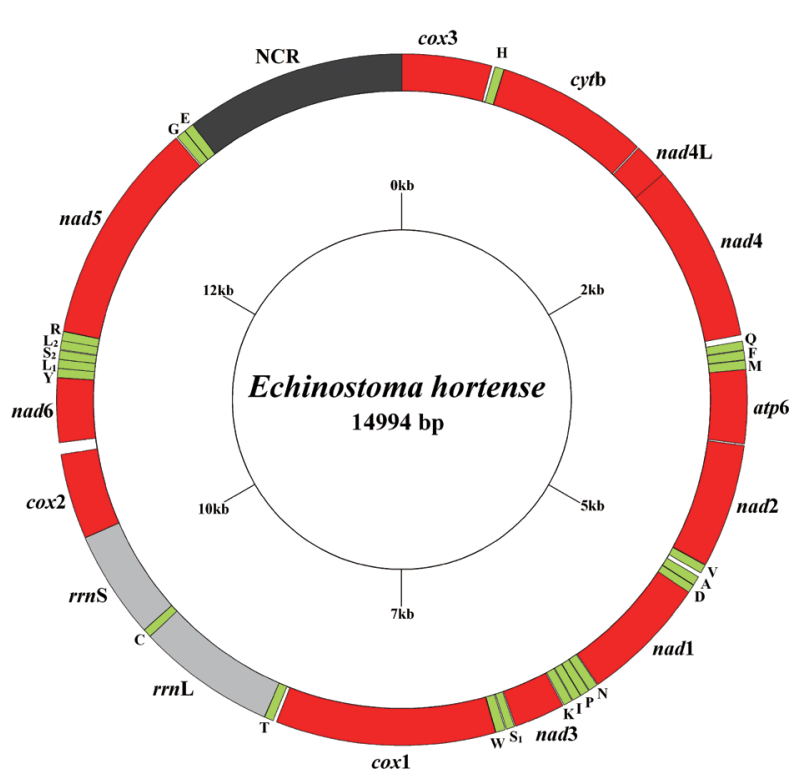

Fig. 1. Arrangement of the mitochondrial genome for Echinostoma hortense. Gene scaling is approximate only. All genes have standard nomenclature, including the 22 tRNA genes, which are designated by the one-letter code for the corresponding amino acid, with numerals differentiating each of the 2 leucine and serine specifying tRNAs ( $L 1$ and $L 2$ for codon families CUN and UUR, respectively; S1 and S2 for codon families AGC and UCA, respectively). mt genome, and the length of PCGs was in the order: nad5> cox $1>$ nad $4>$ cytb $>$ nad $1>n a d 2>\operatorname{cox} 3>\operatorname{cox} 2>$ atp $6>$ nad $6>$ nad $3>$ nad $4 \mathrm{~L}$. The concatenated nucleotide sequences of 12 PCGs were 10,047 bp in length and composed of $45.13 \% \mathrm{~T}, 18.54 \%$ A, $24.73 \% \mathrm{G}$, and $11.60 \% \mathrm{C}$, with A+T accounting for $63.67 \%$ of the total nucleotides encoding the 12 PCGs. The initiation and termination codons of the above amino acid sequences were identified by sequence comparison with homologs in the $\mathrm{mt}$ genomes of other trematodes. The ATG codon was used in 8 PCGs (cox3, cytb, nad4, nad2, nad1, nad3, cox2, and nad5), and the GTG codon in 4r genes (nad4L, atp6, cox1, and nad5) as start codons. The TAG was used as stop codon in 5 genes (cytb, atp6, nad1, nad3, and cox2) and the TAA termination codon in the remaining 7 genes (cox3, nad4L, nad4, nad2, cox1, nad6, and nad5).

Total 22 tRNA genes, which ranged from 59 to $69 \mathrm{bp}$ in length, were predicted from the mt genomes. Among the 22 tRNA genes, tRNA-Ser ${ }^{A \mathrm{AGC}}$ and tRNA-Ser ${ }^{\mathrm{UCA}}$ have unpaired Darms which are replaced by the loops of 7-15 bp, but other 20 tRNA genes could be folded into the conventional cloverleaf structure (data not shown). The 2 ribosomal RNA genes were inferred, $r r n \mathrm{~L}$ was located between tRNA-Thr and tRNA-Cys, and $r r n S$ was located between tRNA-Cys and cox2. The $r r n \mathrm{~L}$ and $r m S$ of $E$. hortense were $973 \mathrm{bp}$ and $759 \mathrm{bp}$ in length, respectively. The A+T contents of the $r r n \mathrm{~L}$ and $r m \mathrm{~S}$ of $E$. hortense $\mathrm{mt}$ genome were $61.63 \%$ and $61.00 \%$, respectively. Only 1 ATrich non-coding region was inferred in the $\mathrm{mt}$ genome, and the AT-rich region located between nad5 and cox3, which is 1,553 bp long with A+T of $64.58 \%$.

\section{Phylogenetic analysis}

Phylogenetic analysis of concatenated nucleotide sequence datasets for all 12 PCGs were performed using MP method, and the result showed that Opisthorchiidae, Heterophyidae, Paragonimidae, Dicrocoeliidae, Fasciolidae, Echinostomatidae, Paramphistomidae, Notocotylidae, and Clinostomidae formed 1 group, whereas Schistosomatidae formed another group (Fig. 2). In former group, besides the bird fluke Clinostomum complanatum, other trematodes gathered together and formed 1 clade. In this clade, Fasciolidae, Echinostomatidae, Paramphistomidae, Notocotylidae, and Clinostomidae trematodes belonged to order Echinostomida all formed monophyly. E. hortense and H. conoideum gathered together, and they were closer to each other than to the Fasciolidae and order Echinostomida trematodes with high nodal support (Fig. 2). 
Table 2. The organization of mitochondrial genome of Echinostoma hortense

\begin{tabular}{|c|c|c|c|c|c|c|}
\hline \multirow{2}{*}{ Gene/Region } & \multicolumn{2}{|c|}{ Positions } & \multicolumn{2}{|c|}{ No. of } & \multicolumn{2}{|c|}{ Codons } \\
\hline & Start (5') & End $\left(3^{\prime}\right)$ & Nucleotides & Aminoacids & Initiation & Termination \\
\hline $\operatorname{cox} 3$ & 1 & 630 & 630 & 209 & ATG & TAA \\
\hline tRNA-His & 652 & 716 & 65 & & & \\
\hline cytb & 718 & 1,791 & 1,074 & 357 & ATG & TAG \\
\hline nad4L & 1,802 & 2,089 & 288 & 95 & GTG & TAA \\
\hline nad4 & 2,050 & 3,297 & 1,248 & 415 & ATG & TAA \\
\hline tRNA-GIn & 3,342 & 3,403 & 62 & & & \\
\hline tRNA-Phe & 3,408 & 3,471 & 64 & & & \\
\hline tRNA-Met & 3,475 & 3,539 & 65 & & & \\
\hline atp6 & 3,540 & 4,055 & 516 & 171 & GTG & TAG \\
\hline nad2 & 4,066 & 4,935 & 870 & 289 & ATG & TAA \\
\hline tRNA-Val & 4,939 & 5,001 & 63 & & & \\
\hline tRNA-Ala & 5,032 & 5,096 & 65 & & & \\
\hline tRNA-Asp & 5,100 & 5,162 & 63 & & & \\
\hline nad1 & 5,158 & 6,057 & 900 & 299 & ATG & TAG \\
\hline tRNA-Asn & 6,063 & 6,129 & 67 & & & \\
\hline tRNA-Pro & 6,134 & 6,196 & 63 & & & \\
\hline tRNA-lle & 6,200 & 6,261 & 62 & & & \\
\hline tRNA-Lys & 6,267 & 6,332 & 66 & & & \\
\hline nad3 & 6,340 & 6,696 & 357 & 118 & ATG & TAG \\
\hline tRNA-SerAGC & 6,704 & 6,762 & 59 & & & \\
\hline tRNA-Trp & 6,771 & 6,838 & 68 & & & \\
\hline $\operatorname{cox} 1$ & 6,842 & 8,383 & 1,542 & 513 & GTG & TAA \\
\hline tRNA-Thr & 8,409 & 8,473 & 65 & & & \\
\hline$r r n L$ & 8,474 & 9,446 & 973 & & & \\
\hline tRNA-Cys & 9,447 & 9,506 & 60 & & & \\
\hline$r r n s$ & 9,507 & 10,265 & 759 & & & \\
\hline $\cos 2$ & 10,266 & 10,865 & 600 & 199 & ATG & TAG \\
\hline nad6 & 10,948 & 11,397 & 450 & 149 & ATG & TAA \\
\hline tRNA-Tyr & 11,399 & 11,462 & 64 & & & \\
\hline tRNA-Leu ${ }^{\mathrm{CUA}}$ & 11,463 & 11,525 & 63 & & & \\
\hline tRNA-Ser UCA & 11,526 & 11,587 & 62 & & & \\
\hline tRNA-Leu UUA & 11,593 & 11,656 & 64 & & & \\
\hline tRNA-Arg & 11,655 & 11,719 & 65 & & & \\
\hline nad5 & 11,722 & 13,293 & 1,572 & 523 & GTG & TAA \\
\hline tRNA-Gly & 13,304 & 13,370 & 67 & & & \\
\hline tRNA-Glu & 13,373 & 13,441 & 69 & & & \\
\hline NC (64.58\%) & 13,442 & 14,994 & 1,553 & & & \\
\hline
\end{tabular}

\section{DISCUSSION}

The complete mt genome of E. hortense (14,994 bp) is smaller than those of Eurytrema pancreaticum (15,031 bp), $H$. taichui (15,130 bp), M. yokogawai (15,258 bp), S. haematobium (15,003 bp), and S. spindale (16,901 bp), but slightly larger than those of other digenean species available in GenBank to date. The $\mathrm{mt}$ genome of $E$. hortense lacks atp 8 gene, which is similar to the mt genomes of other trematodes $[12,13,16,18]$. All genes were transcribed in the same direction, which is consistent with the mt genomes of other digeneans $[12,13,16,18,24]$.
The gene arrangement of 36 genes in $E$. hortense was the same as that of the H. conoideum (KM111525), P. cervi (KF475773), D. dendriticum (NC_025280), and D. chinensis (NC_025279), but different from that of other digenean species. Notably, there was a 28-64 bp long overlap between nad4L and nad4 in fluke mt genomes, but mostly was 28 bp or 40 bp in length. In $E$. hortense, nad4L and nad4 overlapped by $40 \mathrm{bp}$ in size which is consistent with that of O. felineus, C. sinensis, F. hepatica, P. westermani, P. cervi, and H. taichui $[13,16,18,24,25]$. Though $E$. hortense and $H$. conoideum belong to the same family of Echinostomatidae, the lengthes of their cox3 genes were very differ- 


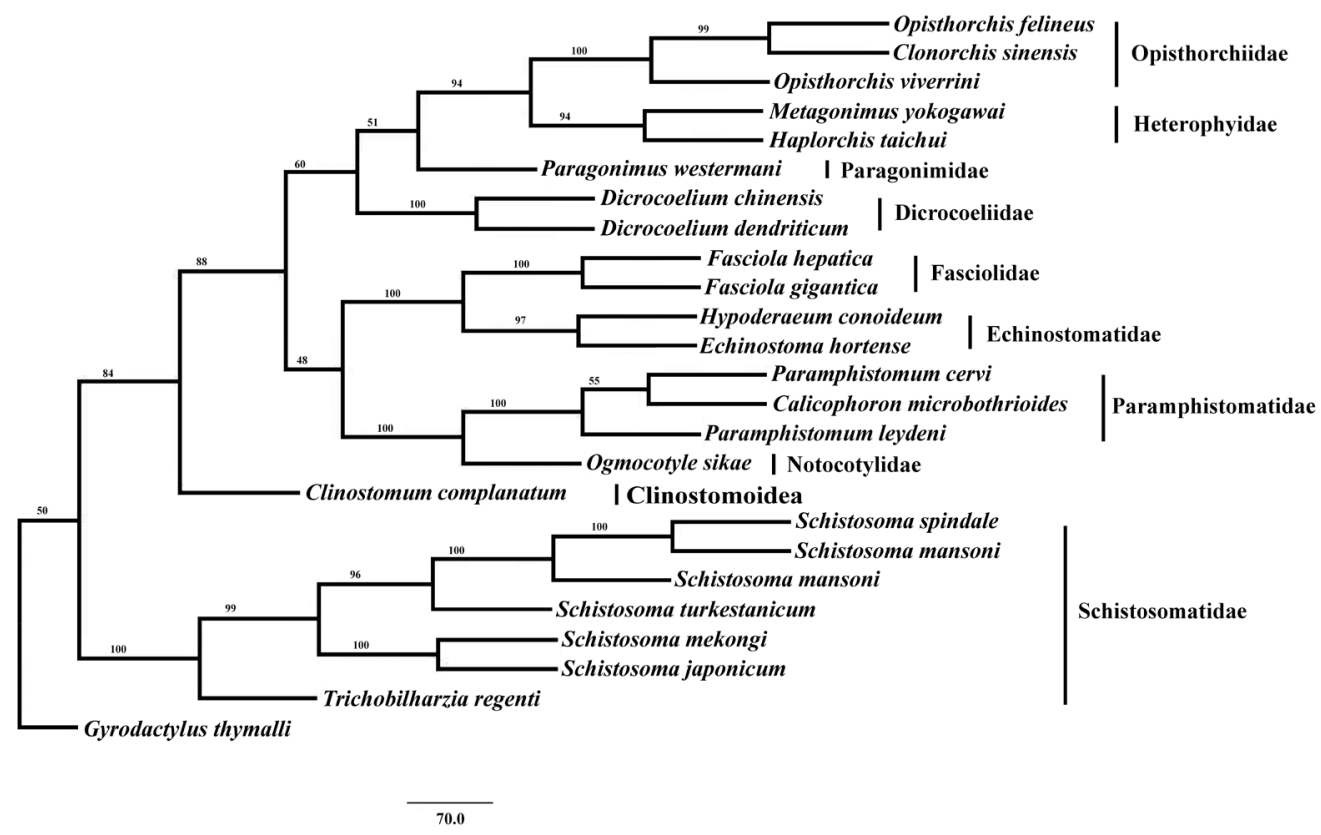

Fig. 2. Phylogenetic relationship of Echinostoma hortense with other digenean trematodes based on mitochondrial genome sequence data. The concatenated amino acid sequences of 12 protein-coding genes were analyzed with maximum parsimony (MP) method, using Monogenean species Gyrodactylus thymalli (NC_009682) as the outgroup.

ent, with that of E. hortense shorter than H. conoideum by 312 bp.

The mt genome of $E$. hortense had 22 tRNA genes, like the majority of trematode mt genome sequences, except for that of P. westermani Korean isolate (NC_002354) and Indian isolate which have 23 and 24 tRNAs [24], respectively. The $r m L$ of E. hortense, at $973 \mathrm{bp}$, was the shortest among trematodes recorded yet, and the rrnS (759 bp) within the range of typical sizes for digenean $\mathrm{mt}$ genomes (700-800 bp). Usually, the size of non-coding region of trematode mt genome is between 55 bp and 2,500 bp, some of the trematode mt genomes have 2 non-coding regions (F. hepatica, F. gigantica, P. cervi, D. dendriticum, and D. chinensis), and a few flukes only contain 1 region (T. regenti, S. mekongi, H. conoideum, and H. taichui). Similarly, the mt genome of $E$. hortense only contains 1 non-coding region. In most trematode mt genomes, between genes or between tRNAs, there are many intergenic sequences with their lengths ranging usually from $1 \mathrm{bp}$ to $50 \mathrm{bp}$, and the longest intergenic region in $E$. hortense $\mathrm{mt}$ genome reached $82 \mathrm{bp}$, but it was not AT-rich (45.12\%) region.

There were many studies about phylogenetic status in the family Echinostomatidae have been done by some researchers. For example, Kudlai et al. [26] used 28S rDNA to study the phylogeny of 25 species of the superfamily Echinostomatoidea by Bayesian analysis. The results showed that 6 clades were clustered, and family Echinostomatidae was the largest group. Echinostoma and Echinoparyphium clustered together in a weakly-supported clade while the members of the other genera formed a 100\% supported grouping. Echinostoma had a closer relationship with Echinoparyphium than to other genera of the family Echinostomatidae. In order to assess the relationships of Echinostoma with other closely related echinostomatids, 37 nad 1 sequences and 15 ITS sequences of the genera Echinostoma, Echinoparyphium, Isthmiophora, and Hypoderaeum were analyzed by Kostadinova et al. [27]. The results showed that the genus Echinostoma is not a monophyletic group, and that $E$. hortense is most distantly related with other Echinostoma trematodes. This result was reconfirmed by Saijuntha et al. [28], who studied the phylogenetic relationships of Echinostoma and Hypoderaeum based on the cox 1 sequences, and the results revealed that E. revolutum and E. malayanum of genus Echinostoma did not form a monophyletic clade and/or sister taxa. In contrast, a study of the phylogenetic relationships of North American echinostomes indicated that the genus Echinostoma is monophyletic, and the genera Hypoderaeum and Echinoparyphium are closely related as sister genera [29]. These contradictory results may be related to differences in geographical localities, sampled numbers, and the snail hosts of the echino- 
stomes.

Therefore, Saijuntha et al. [28] suggested that the traditional morphological taxonomy of echinostomes, which is based on the size, shape, and arrangement of collar spines, the development of circumoral disc and also the testicular shape, should be reconsidered. The phylogenetic analysis in the present study indicated that the 2 fluke species, E. hortense and H. conoideum, of the family Echinostomatidae gathered together, which were closely related than to trematodes of the family Fasciolidae and other Echinostomida trematodes with high nodal support. This result was similar to the findings of previous reports. Although E. hortense and $H$. conoideum $\mathrm{mt}$ genomes were sequenced, more sequences of echinostomatid trematodes $\mathrm{mt}$ genomes are still needed to assess the phylogenetic relationships of these trematodes.

In conclusion, the present study determined the complete $\mathrm{mt}$ genome sequences of $\mathrm{E}$. hortense, the first $\mathrm{mt}$ genome sequence of the genus Echinostoma of Echinostomatidae. The mtDNA dataset provided robust genetic evidence that $E$. hortense and $H$. conoideum were closer to each other than to the Fasciolidae and other Echinostomida trematodes, as well as provided new and useful genetic marker for further studies of the taxonomy, identification, and systematics of echinostomatid flukes.

\section{ACKNOWLEDGMENTS}

This work was supported, in part, by the Fund for Imported Talents in Heilongjiang Bayi Agricultural University (XYB201407), and the Open Funds of the State Key Laboratory of Veterinary Etiological Biology, Lanzhou Veterinary Research Institute, Chinese Academy of Agricultural Sciences (grant no. SKLVEB2014KFKT006).

\section{CONFLICT OF INTEREST}

We have no conflict of interest related to this study.

\section{REFERENCES}

1. Yamaguti S. Synopsis of digenetic trematodes of vertebrates. Tokyo, Japan. Keigaku Publishing Co. 1971, pp 277-323.

2. Chai JY, Shin EH, Lee SH, Rim HJ. Foodborne intestinal flukes in Southeast Asia. Korean J Parasitol 2009; 47 (suppl): S69-S102.

3. Lee SK, Chung NS, Ko IH, Ko HI, Chai JY. Two cases of natural human infection by Echinostoma hortense. Korean J Parasitol
1986; 24: 77-81.

4. Asada J. On a new echinostomatid trematode and its life history. Trans Jpn Soc Pathol 1926; 16: 293-294.

5. Chai JY, Park JH, Jung BK, Guk SM, Kim JL, Shin EH, Klein TA, Kim HC, Chong ST, Baek LJ, Song JW. Echinostome infections in the striped-field mouse, Apodemus agrarius, and the Ussuri white-toothed shrew, Crocidura lasiura, caught near the demilitarized zone, Gyeonggi-do (Province), Republic of Korea. Korean J Parasitol 2009; 47: 311-314.

6. Jiang XL, Guan GJ, Yan JB. The significance of the Echinostoma hortense found in the pig in Sichuan. Agr Sci Rep 1985; 2: 82-84 (in Chinese).

7. Cho SY, Kang SY, Ryang YS. Helminthes infections in the small intestine of stray dogs in Ejungbu city, Kyunggi do, Korea. Korean J Parasitol 1981; 19: 55-59.

8. Chai JY, Bahk YY, Sohn WM. Trematodes recovered in the small intestine of stray cats in the Republic of Korea. Korean J Parasitol 2013; 51: 99-106.

9. Fan SQ, Sun MF. A case of Echinostoma hortense first found in human body in China and morphological observation of the worm. J Harbin Med Univ 1989; 23: 161-163 (in Chinese).

10. Arizono N, Uemoto K, Kondo K, Matsuno K, Yoshida Y, Maeda T, Yoshida H, Muto K, Inoue Z, Takahashi K. Studies on Echinostoma hortense Asada, 1926 with special reference to its human infection. Jpn J Parasitol 1976; 1: 36-45 (in Japanses).

11. Son WY, Huh S, Lee SU, Woo HC, Hong SJ. Intestinal trematode infections in the villagers in Koje-myon, Kochang-gun, Kyongsangnam-do, Korea. Korean J Parasitol 1994; 32: 149-155.

12. Wang Y, Wang CR, Zhao GH, Gao JF, Li MW, Zhu XQ. The complete mitochondrial genome of Orientobilharzia turkestanicum supports its affinity with African Schistosoma spp. Infect Genet Evol 2011; 11: 1964-1970.

13. Lee D, Choe S, Park H, Jeon HK, Chai JY, Sohn WM, Yong TS, Min DY, Rim HJ, Eom KS. Complete mitochondrial genome of Haplorchis taichui and comparative analysis with other trematodes. Korean J Parasitol 2013; 51: 719-726.

14. Cribb TH, Bray RA, Littlewood DTJ, Pichelin SP, Herniou EA. The Digenea. In Littlewood DTJ, Bray RA, eds, Interrelationships of the Platyhelminthes. London, UK. Taylor and Francis. 2001, pp 168-185.

15. Cho CM, Tak WY, Kweon YO, Kim SK, Choi YH, Kong HH, Chung DI. A human case of Echinostoma hortense (Trematoda: Echinostomatidae) infection diagnosed by gastroduodenal endoscopy in Korea. Korean J Parasitol 2003; 41: 117-120.

16. Le TH, Blair D, McManus DP. Complete DNA sequence and gene organization of the mitochondrial genome of the liverfluke, Fasciola hepatica L. (Platyhelminthes: Trematoda). Parasitology 2001; 123: 609-621.

17. Burland TG. DNASTAR's Lasergene sequence analysis software. Methods Mol Biol 2000; 132: 71-91.

18. Shekhovtsov SV, Katokhin AV, Kolchanov NA, Mordvinov VA. The complete mitochondrial genomes of the liver flukes Opisthorchis felineus and Clonorchis sinensis (Trematoda). Parasitol Int 
2010; 59: 100-103.

19. Tamura K, Peterson D, Peterson N, Stecher G, Nei M, Kumar S. MEGA5: Molecular evolutionary genetics analysis using maximum likelihood, evolutionary distance, and maximum parsimony methods. Mol Biol Evol 2011; 28: 2731-2739.

20. Kearse M, Moir R, Wilson A, Stones-Havas S, Cheung M, Sturrock S, Buxton S, Cooper A, Markowitz S, Duran C, Thierer T, Ashton B, Meintjes P, Drummond A. Geneious Basic: an integrated and extendable desktop software platform for the organization and analysis of sequence data. Bioinformatics 2012; 28: 1647-1649.

21. Thompson JD, Gibson TJ, Plewniak F, Jeanmougin F, Higgins DG. The CLUSTAL_X windows interface: flexible strategies for multiple sequence alignment aided by quality analysis tools. Nucleic Acids Res 1997; 25: 4876-4882.

22. Swofford DL. PAUP*. Phylogenetic analysis using parsimony (and other methods). Version 4.0b10. Sunderland MA, Sinauer Associates. 2003.

23. Page RD. TreeView: an application to display phylogenetic trees on personal computers. Comput Appl Biosci 1996; 12: 357-358.

24. Biswal DK, Chatterjee A, Bhattacharya A, Tandon V. The mitochondrial genome of Paragonimus westermani (Kerbert, 1878), the Indian isolate of the lung fluke representative of the family
Paragonimidae (Trematoda). Peer J 2014; 2: e484.

25. Yan HB, Wang XY, Lou ZZ, Li L, Blair D, Yin H, Cai JZ, Dai XL, Lei MT, Zhu XQ, Cai XP, Jia WZ. The mitochondrial genome of Paramphistomum cervi (Digenea), the first representative for the family Paramphistomidae. PLoS One 2013; 8: e71300.

26. Kudlai O, Tkach VV, Pulis EE, Kostadinova A. Redescription and phylogenetic relationships of Euparyphium capitaneum Dietz, 1909, the type-species of Euparyphium Dietz, 1909 (Digenea: Echinostomatidae). Syst Parasitol 2015; 90: 53-65.

27. Kostadinova A, Herniou EA, Barrett J, Littlewood DT. Phylogenetic relationships of Echinostoma Rudolphi, 1809 (Digenea: Echinostomatidae) and related genera re-assessed via DNA and morphological analyses. Syst Parasitol 2003; 54: 159-176.

28. Saijuntha W, Sithithaworn P, Duenngai K, Kiatsopit N, Andrews $\mathrm{RH}$, Petney TN. Genetic variation and relationships of four species of medically important echinostomes (Trematoda: Echinostomatidae) in South-East Asia. Infect Genet Evol 2011; 11: 375381.

29. Detwiler JT, Bos DH, Minchella DJ. Revealing the secret lives of cryptic species: examining the phylogenetic relationships of echinostome parasites in North America. Mol Phylogenet Evol 2010; 55: 611-620. 